\title{
Assessing the influence of construction and demolition waste materials on workability and mechanical properties of concrete using statistical analysis
}

\author{
Bahareh Hadavand ${ }^{1} \cdot$ Reza Imaninasab ${ }^{2}$ \\ Received: 4 December 2018 / Accepted: 15 April 2019 / Published online: 22 April 2019 \\ (c) The Author(s) 2019
}

\begin{abstract}
In recent decades, because of the massive destruction of old structures, a large amount of construction and demolition (C\&D) waste has been produced. These waste materials have the greatest volume and weight among solid waste with many environmental problems. Reusing them in concrete as substitute to virgin aggregates is considered an efficient practice unless significant mechanical properties and workability degradation occurs. In this study, the effect of different concentrations of C\&D waste $(0 \%, 10 \%, 20 \%, 30 \%$, and $50 \%)$ as coarse aggregates on workability, compressive, tensile, and flexural strengths was investigated at the water-to-cement $(W / C)$ ratios of $0.40,0.45$ and 0.50 . The strengths were measured at the ages of 7 and 28 days. The results proved that $C \& D$ waste has no significant effect on compressive strength, while its negative impact on workability was palpable. With respect to tensile and flexural strength, just 50\% of C\&D waste led to significant reduction.
\end{abstract}

Keywords Construction and demolition waste $\cdot$ Recycled aggregates $\cdot$ Solid waste management $\cdot$ Concrete compressive strength $\cdot$ Concrete workability

\section{Introduction}

Population growth has led to dramatic construction activities growth in big cities, and due to increased demand for residential land, the urban areas have had extensive development. Consequently, the amount of construction solid wastes has increased and municipalities and local governments have faced environmental problems due to lack of land to dispose them. On the other hand, most of the landfills are often in the outskirts of the cities [1] and a large portion of construction debris is dumped near roads and rivers in an uncontrolled way. Not only does this create ugly landscapes, but it also intensifies underground water and soil pollution, deforestation, erosion, and the flood hazard in the region.

Bahareh Hadavand

hadavandb1@gmail.com

Reza Imaninasab

rimanina@purdue.edu

1 Department of Civil and Environmental Engineering, Qom University of Technology, Qom, Iran

2 Lyles School of Civil Engineering, Purdue University, West Lafayette, IN, USA
Recycling these waste materials to fabricate standard products such as structural or non-structural concrete can tackle one of the crucial environmental issues with regard to solid waste materials management. It is estimated that $40 \%$ of the total energy and $50 \%$ of the total natural resources are used in construction activities [2]. Thus, disposing them carelessly involves dismissing huge amount of energy as well as natural resources. However, since the most of lands in the county of Iran are rich alluvial soil, which is the source of coarse and fine aggregates, there are plenty of virgin aggregates and the interest in recycling of $C \& D$ waste materials is low.

The advantages of recycling $C \& D$ waste materials are natural resources preservation, decreased need for disposal sites, and air pollution reduction [3]. Many studies have shown recycled waste materials can be beneficial in terms of greenhouse gas emissions because recycling eliminates $\mathrm{CO}_{2}$ gas emissions from landfills and due to the process of extraction of aggregates from natural mines [4]. Moreover, the depletion of non-renewable resources has made the use of recycled materials more demanding.

In order to reuse $C \& D$ materials as aggregates, components such as plastics, metals, plaster, and wood need to be removed from them before crushing into small pieces 
and application as aggregates in concrete or asphalt production $[5,6]$. In recent years, several researchers have studied the use of recycled aggregates as substitute for natural aggregates in concrete production [7-11]. However, the results of the researches vary with the source of recycle aggregates variation. The composition of $C \& D$ materials, the quality of them, and the percentage of virgin aggregates replaced by recycled ones affect the properties and performance of the concrete.

Furthermore, in order to comprehensively assess the influence of specific C\&D materials under study on properties of concrete, it is crucial to not only incorporate important influential factors to manipulate with them, but also consider all conventional properties of the fresh and hardened concrete. Therefore, under various conditions, it is possible to understand which combinations of conditions have no negative effect on properties and, subsequently, are acceptable. A valid investigation of such selection of combinations must involve statistical analysis since all testing results are prone to errors. Although many studies have been conducted on characteristics of concrete containing $C \& D$ waste materials, there are lack of studies with respect to statistical analysis that included all important factors and properties. This is of great importance as we can find confidently which conditions have significant (meaningful) negative and/or positive significant influence on both strength and workability.

Therefore, in this study, the interaction of $W / C$ ratio(s) and $\mathrm{C} \& \mathrm{D}$ waste concentration(s) based upon workability, compressive, tensile, and flexural strengths was determined using statistical analysis. Workability and the aforementioned mechanical properties of concrete were studied with respect to three variables: curing time, percentage of C\&D waste materials, and water-to-cement ratios. These properties were examined at curing ages of 7 and 28 days; water-to-cement ratios of $0.4,0.45$, and 0.5 ; and five different percentages of $0 \%, 10 \%, 20 \%, 30 \%$, and $50 \%$ of recycled coarse aggregates substituting the natural aggregate. After performing the tests at different combinations of conditions, statistical analysis was conducted to assess if the effect of each variable is significant or not.

Bearing in mind that natural resources are depleting and environmental problems are becoming more under scrutiny, there is a fast growing trend in recycling of $C \& D$ waste materials [12]. Yet, it was clarified that, from source to source, properties of concrete containing $C \& D$ materials differ, so general conclusion cannot be drawn. The finding of this study reveals an approach that can be applied for any C\&D materials and let engineers find combinations of effective factors that lead to no degradation in important properties of fresh and hardened concrete.

\section{Literature review}

Rougher shape of recycled aggregates (RA) compared to virgin aggregates (VA) causes some changes in workability. According to the research work by Eckert and Oliveira [1], even if recycled materials are pre-saturated, there is a potential in workability reduction due to the high shape index of recycled materials. Mas et al. [13] observed that slump decreased $66 \%$ by $50 \%$ replacement of RA.

The most important feature for evaluating the structural performance of concrete is compressive strength [4]. Although in some cases increases in compressive strength were observed [14], the compressive strength of concretes containing RA is usually lower than those containing VA $[15,16]$. Such inconsistency in compressive strength relies on the type and concentration of RA, water-to-cement ratio, and aggregates moisture condition $[17,18]$. Castro and de Brito [19] used glass waste as coarse and fine aggregates in concrete, and the results showed that $20 \%$ replacement of coarse and fine VA by RA leads to $3 \%$ and $14 \%$ decreases in compressive strength, respectively. Thus, the impact of fine replacement on compressive strength is more detrimental compared to coarse replacement. Anderson et al. [20] evaluated the compressive strength of concretes containing three different types of ceramic waste as coarse aggregates at concentrations of $20 \%, 25 \%, 35 \%$, $50 \%, 65 \%, 75 \%$, and $100 \%$. It was proved that ceramic can be a suitable alternative for virgin aggregates with minimal changes in compressive strength and other mechanical properties of concrete. Carneiro et al. [18] carried out a research on the influence of the replacement of coarse VA with coarse RA on the mechanical strength. The concretes produced by combining $\mathrm{C} \& \mathrm{D}$ waste materials and VA were found capable of increasing the strength at $25 \%$ of RA. Roa et al. [21] obtained results indicating losses of $15-20 \%$ in tensile strength for total replacement.

\section{Material}

\section{Virgin aggregates (VA)}

The virgin aggregates used in this study were siliceous that were supplied from a local quarry. As shown in Fig. 1, the gradation of fine and coarse natural aggregates with maximum size of $22 \mathrm{~mm}$ was selected so that they fall within upper and lower limits of Iran concrete standard. The fineness modulus was 3 , and the percentage of particle size smaller than $0.075 \mathrm{~mm}$ (sieve \#200) was less than $5 \%$, which meets the specifications of the national standard [22]. $50 \%$ of coarse aggregates and $50 \%$ of fine aggregates were blended to reach a particle size distribution 
Fig. 1 Fine and coarse aggregates gradation

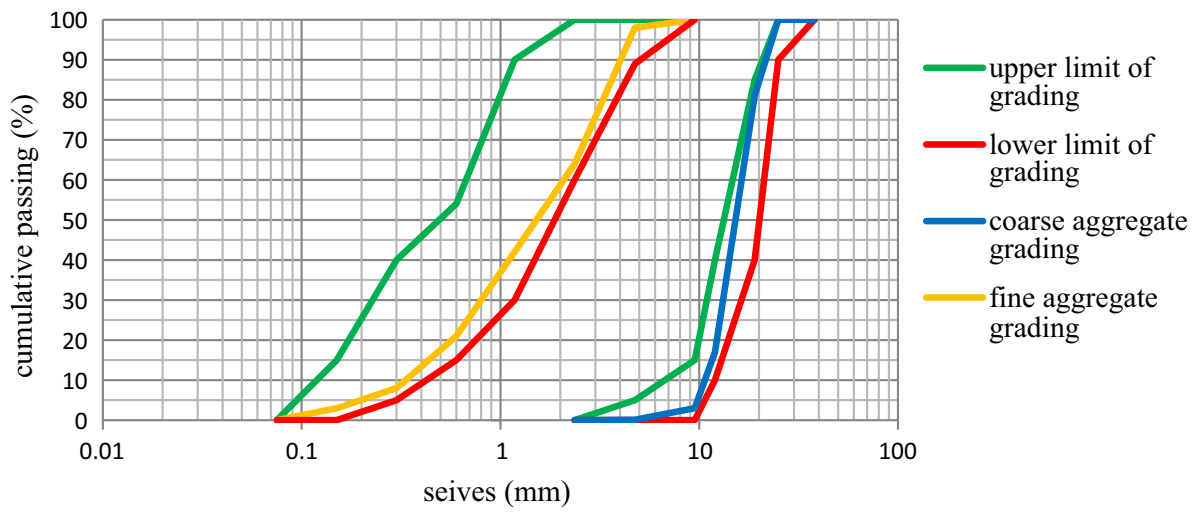

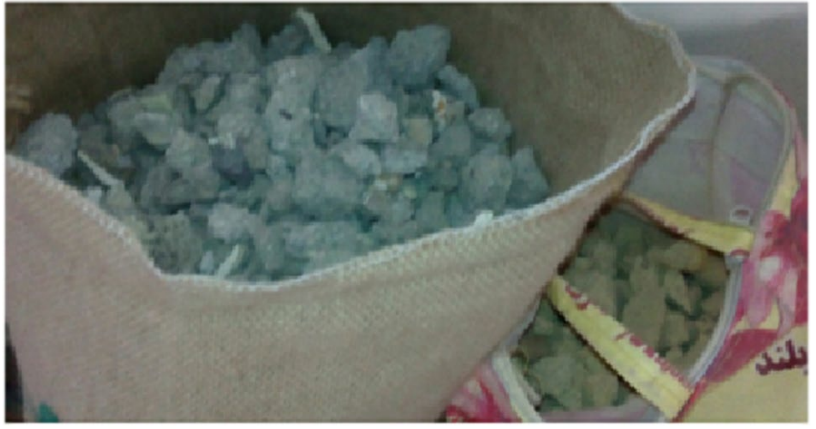

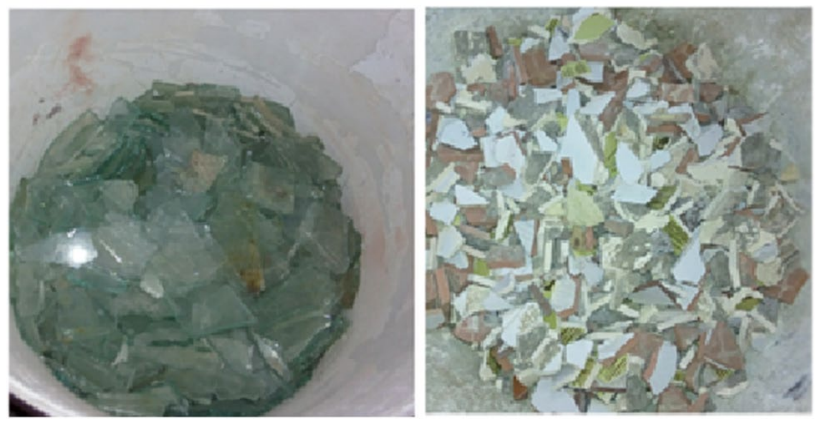

Fig. 3 Recycled aggregates

that for coarse VA. Therefore, replacing coarse VA with RA did not violate the gradation.

Physical properties of VA and RA are listed in Table 1. Water absorption of RA is quite higher than that of VA. This is mainly due to the greater permeable pores and cavities of RA compared to VA. In order to enhance workability, the recycled materials were pre-saturated. Furthermore, the abrasion resistance of VA is higher than RA since the cohesion of VA as a homogeneous substance is greater than that of RA, which is a composite. It can be inferred from abrasion and absorption that, supposedly, the concrete mixture containing RA has lower durability; however, the aim of the present research is not to investigate it. 
Table 1 Physical properties of aggregates

\begin{tabular}{lllll}
\hline Property & Standard & Virgin & Recycled \\
\cline { 3 - 4 } & & Fine & Coarse & \\
\hline Absorption (\%) & ASTM C127-C128 & 2.3 & 0.9 & 7.66 \\
Fineness modulus & ASTM C136 & 3 & - & - \\
Los Angeles abrasion (\%) & ASTM C131 & - & 33 & 57.5 \\
Moisture content $(\%)$ & ASTM C & 0.89 & 0.94 & 0.86 \\
Bulk specific gravity $\left(\mathrm{gr} / \mathrm{cm}^{3}\right)$ & ASTM C127-C128 & 2.60 & 2.64 & 2.12 \\
Apparent specific gravity $\left(\mathrm{gr} / \mathrm{cm}^{3}\right)$ & ASTM C127-C128 & 2.74 & 2.72 & 2.19 \\
\hline
\end{tabular}

\section{Portland composite cement}

Portland composite cement (PCC) type I (general use) was used in this study. It has a 28-day compressive strength of $325 \mathrm{~kg} / \mathrm{Cm}^{2}$, and its specific gravity is $3.14 \mathrm{~g} / \mathrm{cm}^{3}$. The percentages of chemical elements of the cement are $\mathrm{SiO}_{2}$ : 19.3\%, Cao: 57.7, $\mathrm{Fe}_{2} \mathrm{O}_{3}: 4.32, \mathrm{Al}_{2} \mathrm{O}_{3}: 4.42, \mathrm{Na}_{2} \mathrm{O}: 0.16 \%$, $\mathrm{K}_{2} \mathrm{O}: 0.28, \mathrm{SO}_{3}: 2.32$, and LI: 9.78 .

\section{Research approach}

\section{Mix design and sample preparation}

There are five different RA contents including 0, 10, 20, 30 , and $50 \%$ that each percentage was prepared at $3 \mathrm{~W} / \mathrm{C}$ ratios of $0.4,0.45$, and 0.5 , so, as indicated in Table 3 , it comprises 15 types of concrete. Proportioning of concrete mix was carried out based on volumetric properties for nonair-entrained concrete. The weight of each component of various concrete types in one cubic meter volume of concrete is given in Table 2 .

To investigate the effect of recycled aggregates on compressive strength of concrete, 90 cubic $150 \times 150 \times 150 \mathrm{~mm}$ specimens were fabricated. Being extracted from molds after $24 \mathrm{~h}$, half of the specimens underwent a curing period 7 days and the rest 28 days in water bath at room temperature of $25 \pm 3{ }^{\circ} \mathrm{C}$. Similarly, $150 \times 300 \mathrm{~mm}$ cylindrical specimens for tensile strength test and $100 \times 100 \times 500 \mathrm{~mm}$ beam specimens for flexural strength test were prepared and cured for 7 and 28 days.

\section{Testing program}

The tests that were performed on the different types of concrete mixtures included slump, compressive, tensile, and flexural strength tests. The slump test was implemented on fresh concrete right after mixing based on ASTM C143. The concrete compressive, tensile, and flexural strength tests were performed according to BS 1881-116, ASTM C49696, and ASTM C1018 standards, respectively. For each type
Table 2 Mix design for $1 \mathrm{~m}^{3}$ of concrete

\begin{tabular}{lllllcc}
\hline Mixture & $W / C$ & $\begin{array}{l}\text { Cement } \\
\left(\mathrm{kg} / \mathrm{m}^{3}\right)\end{array}$ & $\begin{array}{l}\text { Water } \\
\left(\mathrm{kg} / \mathrm{m}^{3}\right)\end{array}$ & $\begin{array}{l}\text { Fine aggregate } \\
\left(\mathrm{kg} / \mathrm{m}^{3}\right)\end{array}$ & $\begin{array}{l}\text { Natural coarse } \\
\text { aggregate } \\
\left(\mathrm{kg} / \mathrm{m}^{3}\right)\end{array}$ & $\begin{array}{l}\text { Recycled coarse } \\
\text { aggregate } \\
\left(\mathrm{kg} / \mathrm{m}^{3}\right)\end{array}$ \\
\hline VAC & 0.4 & 490 & 196 & 790 & 1042 & 0 \\
$10 \%$ RAC & 0.4 & 490 & 196 & 790 & 938 & 104 \\
20\%RAC & 0.4 & 490 & 196 & 790 & 834 & 208 \\
30\%RAC & 0.4 & 490 & 196 & 790 & 729 & 313 \\
50\%RAC & 0.4 & 490 & 196 & 790 & 521 & 521 \\
VAC & 0.45 & 436 & 196 & 790 & 1042 & 0 \\
10\%RAC & 0.45 & 436 & 196 & 790 & 938 & 104 \\
20\%RAC & 0.45 & 436 & 196 & 790 & 834 & 208 \\
30\%RAC & 0.45 & 436 & 196 & 790 & 729 & 313 \\
50\%RAC & 0.45 & 436 & 196 & 790 & 521 & 521 \\
VAC & 0.5 & 392 & 196 & 790 & 1042 & 0 \\
10\%RAC & 0.5 & 392 & 196 & 790 & 938 & 104 \\
20\%RAC & 0.5 & 392 & 196 & 790 & 834 & 208 \\
30\%RAC & 0.5 & 392 & 196 & 790 & 729 & 313 \\
50\%RAC & 0.5 & 392 & 196 & 790 & 521 & 521 \\
\hline
\end{tabular}


of the concrete mixture, the average strength of three replicates was reported as the results for compressive, tensile, and flexural strength tests.

\section{Statistical analysis}

Statistical analysis helps to assess what factors (X) influence a specific response $(\mathrm{R})$ significantly, i.e., the variation in response values as a result of independent variable change from " $a$ " to " $b$ " is not slight and due to experimental errors. In the sensitivity analysis, if the effect of one factor (variable) on the responses is significant, it should be considered as an effective factor. In the present research, factorial experiment was designed in order to find the increment(s) of levels, if any, within which each factor is potentially significant.

In factorial experiment, each factor $(i)$ can have several levels $\left(m_{i}\right)$. Thus, the number of factorial design $(N)$ can be computed by Eq. (1):

$N=\prod_{i=1}^{n} m_{i}$

where $n$ is the number of factors.

The variance of each condition $\left(S_{\mathrm{j}}^{2}\right)$, which means variance of responses (observations) for the factors with specific values (levels), was calculated. Notably, there are total conditions of $N$. Also, the pooled observation variance $\left(S_{\mathrm{p}}^{2}\right)$ is defined as the variance of the total observations and can be calculated using Eq. (2):

$S_{\mathrm{p}}^{2}=\frac{S_{1}^{2}+S_{2}^{2}+\cdots+S_{n}^{2}}{N-1}$

There are two types of effect that can be examined in statistical analysis:

(a) The main effect (ME) which is the average effect of the difference in response due to changing one variable while holding the other constant.

(b) The interaction effect (IE) which is the average effect of the difference in response due to changing more than one variable.

In order to understand the main effect of the factor $X_{1}$, for instance, on the response $R_{1}$ when a specific increment occurs in $X_{1}$ (changing from level " $m$ " to level " $n$ "), Eq. (3) can be used to determine the difference in response:

$\operatorname{ME}\left(X_{1}\right)=\operatorname{Ave}\left(X_{1}=\right.$ level $\left.n\right)-\operatorname{Ave}\left(X_{1}=\right.$ level $\left.m\right)$

All the observations are divided into two parts: those with $X_{1}=$ level $\mathrm{n}$ and others with $X_{1}=$ level $\mathrm{m}$. The means of them are computed and inserted in Eq. (3).

On the other hand, in order to understand the interaction effect of the factors $X_{1}$ and $X_{2}$, for instance, on the response
$R_{1}$ when a specific increment occurs in $X_{1}$ and $X_{2}$ (changing from level " $m$ " to level " $n$ " and from " $k$ " to " $l$ ", respectively), any of the formula presented in Eq. (4) can be used to determine the difference in response:

$$
\begin{aligned}
\operatorname{IE}\left(X_{1}, X_{2}\right)= & 0.5\left[\operatorname{ME}\left(X_{1}: \text { level } m \text { to } n \mid X_{2}=\text { level } l\right)\right. \\
& \left.-\operatorname{ME}\left(X_{1}: \text { level } m \text { to } n \mid X_{2}=\text { level } k\right)\right] \\
\operatorname{IE}\left(X_{2}, X_{1}\right)= & 0.5\left[\operatorname{ME}\left(X_{2}: \text { level } k \text { to } l \mid X_{1}=\text { level } n\right)\right. \\
& \left.-\operatorname{ME}\left(X_{2}: \text { level } k \text { to } l \mid X_{1}=\text { level } m\right)\right]
\end{aligned}
$$

Observations of the two parts that ME causes are restricted to those satisfying the term after the sign "l".

Having $S_{\mathrm{p}}^{2}$, the variance of effect $\left(S_{\text {eff. }}^{2}\right)$ can be computed by Eq. (5), and since each effect is a linear combination of the same all observations, the variance of all effects and the interaction effects is the same.

$S_{\text {eff. }}^{2}=\frac{4 S_{\mathrm{p}}^{2}}{N}$

The null hypothesis assumes a normal distribution for the effects a mean equal to zero $\left(\mu_{\text {eff }}=0\right)$. The null hypothesis is tested by calculating $t$-value of ME or IE using Eq. (6) and comparing the result with $t$-value limit on the basis of $95 \%$ confidence level from $t$-table. If the calculated $t$-value is greater than the $t$-value limit, the effect is significant.

$t$-value $=\frac{E\left(X_{i}\right)}{S_{\text {eff. }}}$

where $E$ can be ME or IE and $S_{\text {eff. }}$ is the square root of $S_{\text {eff: }}^{2}$.

In this study, the effects of three independent explanatory variables (factors) on four response variables were analyzed separately. The response variables were compressive strength $\left(R_{1}\right)$, tensile strength $\left(R_{2}\right)$, flexural strength $\left(R_{3}\right)$, and slump $\left(R_{4}\right)$ of concrete. Main and interaction effects of three factors including curing time $\left(E_{1}\right)$, percentage of C\&D waste $\left(E_{2}\right)$ at, and $W / C$ ratio $\left(E_{3}\right)$ were examined at levels of 7 and 28 days; $0,10,20,30$, and 50\% concentrations; and $0.4,0.45$, and 0.5 ratios, respectively. Thus, using Eq. (1), there are $2 \times 5 \times 3=30$ conditions and the $t$-value is equal to $1.699\left(t_{29,0.5}=1.699\right)$.

\section{Results and discussion}

\section{Properties of fresh concrete}

\section{Workability}

The slump test was performed to evaluate the workability of concrete containing C\&D waste materials. It is of great importance for conveyance, placement, and finishing 
of fresh concrete. $W / C$ ratio of 0.26 provides sufficient water for hydration; however, despite negative impact on strength and durability of hardened concrete, greater $W / C$ is required and applied for workability purposes.

As shown in Fig. 4, the workability increases with the increase in $W / C$ ratio increase, while the addition of RA decreases it. The reduction in workability with RA increase is due to several factors; the greater surface and rougher shape of RA compared to VA provide more inter-particle frictional resistance between particles of recycled concrete which subsequently reduces workability. Also, more voids in RA increase the water absorption of this concrete and lead to less workability [23]. During the mixing, recycled aggregates to some extent turn into smaller particulars. These fine particles with higher surface area tend to absorb greater amount of water than coarse aggregates, so workability decreased with their increase.

\section{Properties of hardened concrete}

\section{Compressive strength}

Compressive strength of concrete is the most fundamental and comprehensive property of hardened concrete from

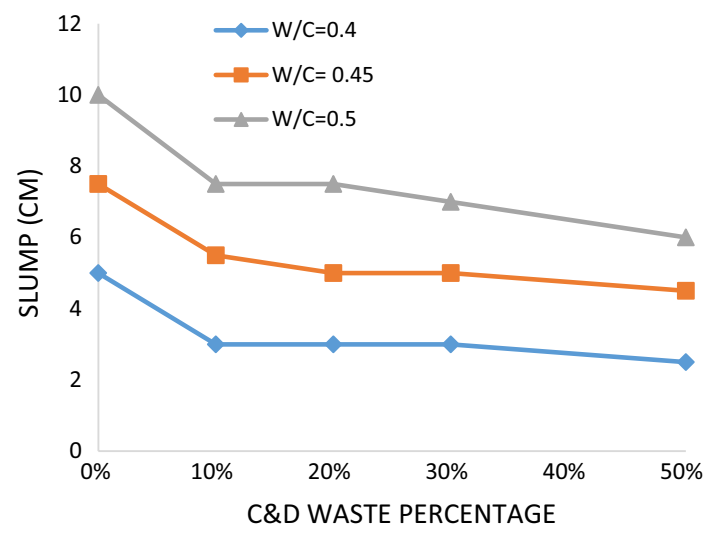

Fig. 4 Variation in workability of concrete with C\&D waste replacement which other properties such as tensile strength and elastic modulus can also be estimated. As shown in Fig. 5, the incorporation of RA in the concrete causes a reduction in compressive strength at all ages. The decrease in strength is observed with increased percentage of RA and water-tocement ratio. It is well established that higher $W / C$ results in lower compressive strength because of higher air voids after hardening. Also, concrete gains strength with aging as cement hydration continues to the end of the concrete life. $\mathrm{C} \& \mathrm{D}$ waste materials have both negative and positive influence on compressive strength, and depending on which one prevails, the overall impact of them on strength can be an increase or a decrease.

The high absorption of water in RA, the poor adhesion between RA, old mortar, and cement paste, which causes transverse cracks in concrete, and the presence of a poor porous mortar around the aggregates are among the RA properties that reduce compressive strength [24]. The surface of recycled concrete aggregates, which constitute half of the RA by weight in this study, is the location for weakness and prone to cracking because of interfacial transition zone between old mortar and new one. This weakness can be a more determinative factor than the strength of the mortar in the compressive strength of the concrete containing RA. Moreover, during mixing RA tend to crumble into finer particles and make the gradation of the concrete mixture finer which, subsequently, causes declining in concrete strength. On the other hand, RA has higher pores and cavities than VA and the cement paste deeply penetrates into its voids which provide interlocking and better bonding between cement paste and RA. This positive effect of RA on compressive strength superposes with the aforementioned negative ones. Generally, the reduction in compressive strength is not noticeable up to $50 \%$ replacement [25].

Comparing Fig. 5a with b, it can be observed that the decrease in strength with $\mathrm{C} \& \mathrm{D}$ waste increase becomes more severe at the age of 28 days compared to 7 days. Furthermore, from Fig. 5a, b, it can be inferred that the 28-day strength decreases slightly from $W / C=0.45$ to $W / C=0.5$,
Fig. 5 Variation in compressive strength of concrete with C\&D waste replacement: $\mathbf{a} 7$ days; $\mathbf{b}$ 28 days

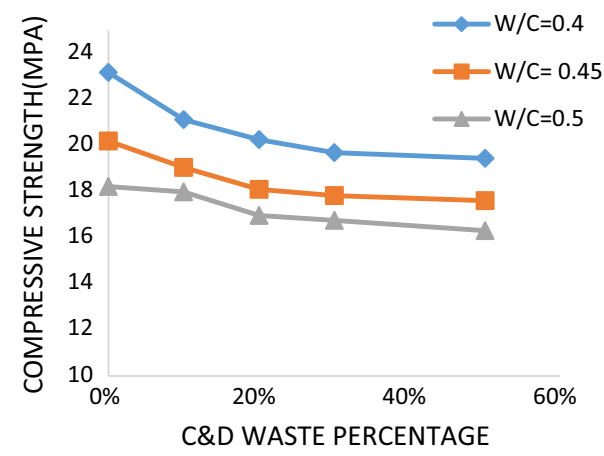

(a)

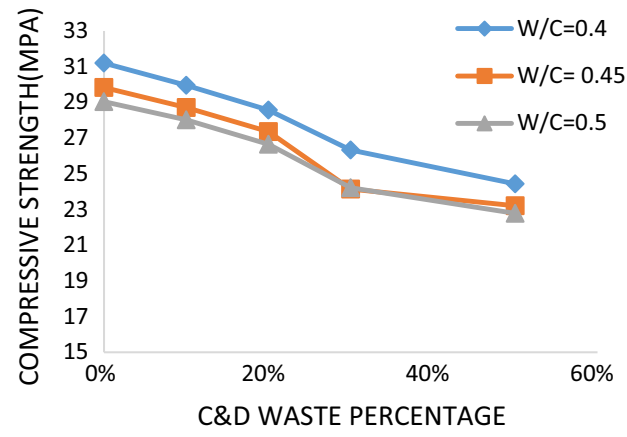

(b) 
while the change in slump is favorable. Therefore, an increment of 0.5 from 0.45 to 0.5 is recommended if there are workability issues.

\section{Tensile strength}

The tensile strength of concrete is far lower than its compressive one. With regard to structural analysis, steel bars are responsible for carrying tensile load and the role of concrete is neglected. However, its tensile strength is important for thermal and shrinkage cracking resistance. It was indicated that, in condition of 50\% RA and 28 days, tensile strength loss is less than $10 \%$ in comparison with the control mixture without RA [16]. However, it cannot be true for all types of VA and RA. As shown in Fig. 6, similar to compressive strength, introduction of RA into concrete leads to tensile strength reduction, and with the percentage of replacement increasing, there is lower tensile strength. Moreover, although the 28-day tensile strength of 0.45 and $0.5 \mathrm{~W} / \mathrm{C}$ ratios at the two extremes, i.e., 0 and $50 \%$, are approximately the same, 10,20 , and $30 \%$ show different values like which is unlike compressive strength trend.

\section{Flexural strength}

The flexural strength incorporates both tensile and compressive properties of concrete. It describes the resistance of the structural members under moment loading. The moment increases until the lowest part of the bending beam reaches its strength and the rupture initiates. After that, the flexural capacity of the beam decreases due to effective cross section reduction. The maximum load in three-point bending beam test is defined as the flexural strength.

Ahmadi et al. [6] proved that the flexural strength of concretes with different percentages of RA is greater than that without RA due to better adhesion between RA and cement paste. However, this result is in contradiction with the results illustrated in Fig. 4 mainly because of a different source of RA. The flexural strength, similar to the compressive and tensile strengths, decreases with the increase in the replacement dosage. Comparing Fig. $7 \mathrm{a}$ with $\mathrm{b}$ reveals that the differences among 28-day flexural strengths of $W / C=0.4, W / C=0.45$, and $W / C=0.5$ lessen at each $C \& D$ waste concentration in comparison with 7-day ones. This indicates the influence of $W / C$ ratio on flexural strength reduces with aging.

\section{Statistical analysis}

In order to assess the influence of a factor or several factors on a response, it is vital to conduct statistical analysis. In this study two-level factorial design was used. The detrimental or beneficial impact of a factor might not be considered as significance once further investigation is done by factorial statistical analysis.
Fig. 6 Variation in tensile strength of concrete with $\mathrm{C} \& \mathrm{D}$ waste replacement: a 7 days; $\mathbf{b}$ 28 days

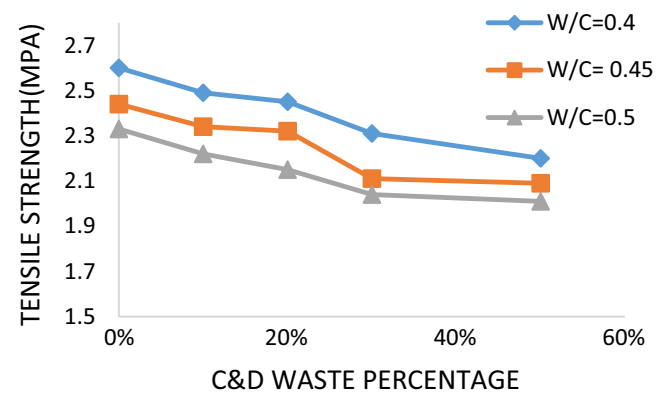

(a)

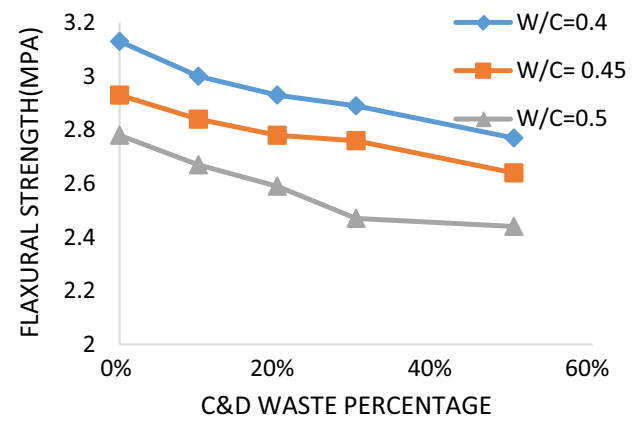

(a)

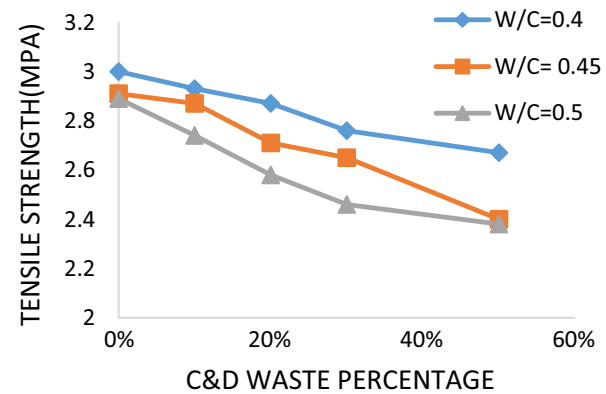

(b)

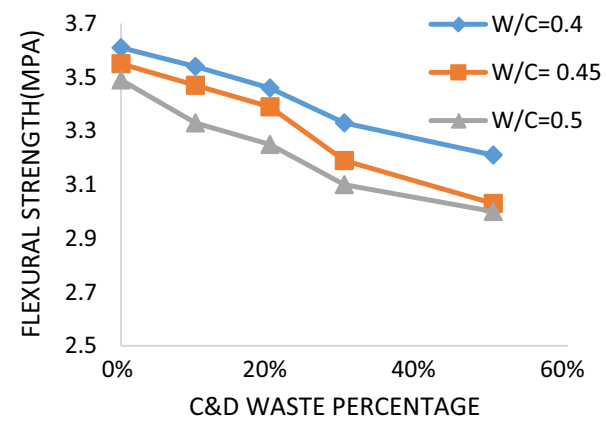

(b) 
Table 3 Statistical analysis

\begin{tabular}{|c|c|c|c|c|c|c|c|c|c|c|c|c|c|}
\hline$C \& D$ waste & $W / C$ & Effects & $R_{1}$ & $R_{2}$ & $R_{3}$ & $R_{4}$ & C\&D waste & $W / C$ & Effects & $R_{1}$ & $R_{2}$ & $R_{3}$ & $R_{4}$ \\
\hline \multicolumn{7}{|c|}{ One level of increment in $C \& D$ waste } & $10-30$ & $0.4-0.45$ & E1 & S & S & $\mathrm{S}$ & ND \\
\hline \multirow[t]{18}{*}{$0-10$} & \multirow[t]{6}{*}{$0.4-0.45$} & E1 & $\mathrm{S}$ & $\mathrm{S}$ & $\mathrm{S}$ & ND & & & E2 & $\mathrm{N}$ & $\mathrm{N}$ & $\mathrm{N}$ & $\mathrm{N}$ \\
\hline & & E2 & $\mathrm{N}$ & $\mathrm{N}$ & $\mathrm{N}$ & $S$ & & & E3 & $\mathrm{N}$ & $\mathrm{N}$ & $\mathrm{N}$ & $\mathrm{S}$ \\
\hline & & E3 & $\mathrm{N}$ & $\mathrm{N}$ & $\mathrm{N}$ & $S$ & & & $\mathrm{E} 1,2$ & $\mathrm{~N}$ & $\mathrm{~N}$ & $\mathrm{~N}$ & ND \\
\hline & & $\mathrm{E} 1,2$ & $\mathrm{~N}$ & $\mathrm{~N}$ & $\mathrm{~N}$ & ND & & & $\mathrm{E} 1,3$ & $\mathrm{~N}$ & $\mathrm{~N}$ & $\mathrm{~N}$ & ND \\
\hline & & $\mathrm{E} 1,3$ & $\mathrm{~N}$ & $\mathrm{~N}$ & $\mathrm{~N}$ & ND & & & $\mathrm{E} 2,3$ & $\mathrm{~N}$ & $\mathrm{~N}$ & $\mathrm{~N}$ & $\mathrm{~N}$ \\
\hline & & $\mathrm{E} 2,3$ & $\mathrm{~N}$ & $\mathrm{~N}$ & $\mathrm{~N}$ & $\mathrm{~N}$ & & $0.45-0.5$ & E1 & $S$ & $S$ & $\mathrm{~S}$ & ND \\
\hline & \multirow[t]{6}{*}{$0.45-0.5$} & E1 & $\mathrm{S}$ & $\mathrm{S}$ & $\mathrm{S}$ & ND & & & E2 & $\mathrm{N}$ & $\mathrm{N}$ & $\mathrm{N}$ & $\mathrm{N}$ \\
\hline & & E2 & $\mathrm{N}$ & $\mathrm{N}$ & $\mathrm{N}$ & S & & & E3 & $\mathrm{N}$ & $\mathrm{N}$ & $\mathrm{N}$ & $\mathrm{S}$ \\
\hline & & E3 & $\mathrm{N}$ & $\mathrm{N}$ & $\mathrm{N}$ & $S$ & & & $\mathrm{E} 1,2$ & $\mathrm{~N}$ & $\mathrm{~N}$ & $\mathrm{~N}$ & ND \\
\hline & & $\mathrm{E} 1,2$ & $\mathrm{~N}$ & $\mathrm{~N}$ & $\mathrm{~N}$ & ND & & & $\mathrm{E} 1,3$ & $\mathrm{~N}$ & $\mathrm{~N}$ & $\mathrm{~N}$ & ND \\
\hline & & $\mathrm{E} 1,3$ & $\mathrm{~N}$ & $\mathrm{~N}$ & $\mathrm{~N}$ & ND & & & $\mathrm{E} 2,3$ & $\mathrm{~N}$ & $\mathrm{~N}$ & $\mathrm{~N}$ & $\mathrm{~N}$ \\
\hline & & $\mathrm{E} 2,3$ & $\mathrm{~N}$ & $\mathrm{~N}$ & $\mathrm{~N}$ & $\mathrm{~N}$ & & $0.4-0.5$ & E1 & $\mathrm{S}$ & $S$ & $\mathrm{~S}$ & ND \\
\hline & \multirow[t]{6}{*}{$0.4-0.5$} & E1 & $\mathrm{S}$ & $\mathrm{S}$ & $\mathrm{S}$ & ND & & & E2 & $\mathrm{N}$ & $\mathrm{N}$ & $\mathrm{N}$ & $\mathrm{N}$ \\
\hline & & E2 & $\mathrm{N}$ & $\mathrm{N}$ & $\mathrm{N}$ & $\mathrm{N}$ & & & E3 & $\mathrm{N}$ & $\mathrm{N}$ & $\mathrm{N}$ & $S$ \\
\hline & & E3 & $\mathrm{N}$ & $\mathrm{N}$ & $\mathrm{N}$ & $S$ & & & $\mathrm{E} 1,2$ & $\mathrm{~N}$ & $\mathrm{~N}$ & $\mathrm{~N}$ & ND \\
\hline & & $\mathrm{E} 1,2$ & $\mathrm{~N}$ & $\mathrm{~N}$ & $\mathrm{~N}$ & ND & & & $\mathrm{E} 1,3$ & $\mathrm{~N}$ & $\mathrm{~N}$ & $\mathrm{~N}$ & ND \\
\hline & & $\mathrm{E} 1,3$ & $\mathrm{~N}$ & $\mathrm{~N}$ & $\mathrm{~N}$ & ND & & & $\mathrm{E} 2,3$ & $\mathrm{~N}$ & $\mathrm{~N}$ & $\mathrm{~N}$ & $\mathrm{~N}$ \\
\hline & & $\mathrm{E} 2,3$ & $\mathrm{~N}$ & $\mathrm{~N}$ & $\mathrm{~N}$ & $\mathrm{~N}$ & $20-50$ & $0.4-0.45$ & E1 & $S$ & S & $\mathrm{S}$ & ND \\
\hline \multirow{18}{*}{$\begin{array}{l}\mathrm{N} \\
10-20\end{array}$} & \multirow[t]{6}{*}{$0.4-0.45$} & E1 & $\mathrm{S}$ & $\mathrm{S}$ & $\mathrm{S}$ & ND & & & E2 & $\mathrm{N}$ & $\mathrm{N}$ & $\mathrm{N}$ & $\mathrm{N}$ \\
\hline & & E2 & $\mathrm{N}$ & $\mathrm{N}$ & $\mathrm{N}$ & $\mathrm{N}$ & & & E3 & $\mathrm{N}$ & $\mathrm{N}$ & $\mathrm{N}$ & $\mathrm{S}$ \\
\hline & & E3 & $\mathrm{N}$ & $\mathrm{N}$ & $\mathrm{N}$ & S & & & $\mathrm{E} 1,2$ & $\mathrm{~N}$ & $\mathrm{~N}$ & $\mathrm{~N}$ & ND \\
\hline & & $\mathrm{E} 1,2$ & $\mathrm{~N}$ & $\mathrm{~N}$ & $\mathrm{~N}$ & ND & & & $\mathrm{E} 1,3$ & $\mathrm{~N}$ & $\mathrm{~N}$ & $\mathrm{~N}$ & ND \\
\hline & & $\mathrm{E} 1,3$ & $\mathrm{~N}$ & $\mathrm{~N}$ & $\mathrm{~N}$ & ND & & & $\mathrm{E} 2,3$ & $\mathrm{~N}$ & $\mathrm{~N}$ & $\mathrm{~N}$ & $\mathrm{~N}$ \\
\hline & & $\mathrm{E} 2,3$ & $\mathrm{~N}$ & $\mathrm{~N}$ & $\mathrm{~N}$ & $\mathrm{~N}$ & & $0.45-0.5$ & E1 & $\mathrm{S}$ & S & $\mathrm{S}$ & ND \\
\hline & \multirow[t]{6}{*}{$0.45-0.5$} & E1 & $\mathrm{S}$ & $S$ & $\mathrm{~S}$ & ND & & & E2 & $\mathrm{N}$ & $\mathrm{N}$ & $\mathrm{N}$ & $\mathrm{N}$ \\
\hline & & E2 & $\mathrm{N}$ & $\mathrm{N}$ & $\mathrm{N}$ & $\mathrm{N}$ & & & E3 & $\mathrm{N}$ & $\mathrm{N}$ & $\mathrm{N}$ & $\mathrm{S}$ \\
\hline & & E3 & $\mathrm{N}$ & $\mathrm{N}$ & $\mathrm{N}$ & S & & & E1,2 & $\mathrm{N}$ & $\mathrm{N}$ & $\mathrm{N}$ & ND \\
\hline & & $\mathrm{E} 1,2$ & $\mathrm{~N}$ & $\mathrm{~N}$ & $\mathrm{~N}$ & ND & & & E1,3 & $\mathrm{N}$ & $\mathrm{N}$ & $\mathrm{N}$ & ND \\
\hline & & $\mathrm{E} 1,3$ & $\mathrm{~N}$ & $\mathrm{~N}$ & $\mathrm{~N}$ & ND & & & $\mathrm{E} 2,3$ & $\mathrm{~N}$ & $\mathrm{~N}$ & $\mathrm{~N}$ & $\mathrm{~N}$ \\
\hline & & $\mathrm{E} 2,3$ & $\mathrm{~N}$ & $\mathrm{~N}$ & $\mathrm{~N}$ & $\mathrm{~N}$ & & $0.4-0.5$ & E1 & $S$ & S & $\mathrm{S}$ & ND \\
\hline & \multirow[t]{6}{*}{$0.4-0.5$} & E1 & S & $\mathrm{S}$ & $\mathrm{S}$ & ND & & & E2 & $\mathrm{N}$ & $\mathrm{N}$ & $\mathrm{N}$ & $\mathrm{N}$ \\
\hline & & E2 & $\mathrm{N}$ & $\mathrm{N}$ & $\mathrm{N}$ & $\mathrm{N}$ & & & E3 & $\mathrm{N}$ & $\mathrm{N}$ & $\mathrm{N}$ & $\mathrm{S}$ \\
\hline & & E3 & $\mathrm{N}$ & $\mathrm{N}$ & $\mathrm{N}$ & $S$ & & & E1,2 & $\mathrm{N}$ & $\mathrm{N}$ & $\mathrm{N}$ & ND \\
\hline & & $\mathrm{E} 1,2$ & $\mathrm{~N}$ & $\mathrm{~N}$ & $\mathrm{~N}$ & ND & & & E1,3 & $\mathrm{N}$ & $\mathrm{N}$ & $\mathrm{N}$ & ND \\
\hline & & $\mathrm{E} 1,3$ & $\mathrm{~N}$ & $\mathrm{~N}$ & $\mathrm{~N}$ & ND & & & $\mathrm{E} 2,3$ & $\mathrm{~N}$ & $\mathrm{~N}$ & $\mathrm{~N}$ & $\mathrm{~N}$ \\
\hline & & $\mathrm{E} 2,3$ & $\mathrm{~N}$ & $\mathrm{~N}$ & $\mathrm{~N}$ & $\mathrm{~N}$ & Three levels $\mathrm{c}$ & rement in & waste & & & & \\
\hline \multirow[t]{10}{*}{$20-30$} & \multirow[t]{6}{*}{$0.4-0.45$} & E1 & $\mathrm{S}$ & $\mathrm{S}$ & $\mathrm{S}$ & ND & $0-30$ & $0.4-0.45$ & E1 & S & S & $\mathrm{S}$ & ND \\
\hline & & E2 & $\mathrm{N}$ & $\mathrm{N}$ & $\mathrm{N}$ & $\mathrm{N}$ & & & E2 & $\mathrm{N}$ & $\mathrm{N}$ & $\mathrm{N}$ & $S$ \\
\hline & & E3 & $\mathrm{N}$ & $\mathrm{N}$ & $\mathrm{N}$ & S & & & E3 & $\mathrm{N}$ & $\mathrm{N}$ & $\mathrm{N}$ & $\mathrm{S}$ \\
\hline & & $\mathrm{E} 1,2$ & $\mathrm{~N}$ & $\mathrm{~N}$ & $\mathrm{~N}$ & $\mathrm{~N}$ & & & $\mathrm{E} 1,2$ & $\mathrm{~N}$ & $\mathrm{~N}$ & $\mathrm{~N}$ & ND \\
\hline & & $\mathrm{E} 1,3$ & $\mathrm{~N}$ & $\mathrm{~N}$ & $\mathrm{~N}$ & $\mathrm{~N}$ & & & $\mathrm{E} 1,3$ & $\mathrm{~N}$ & $\mathrm{~N}$ & $\mathrm{~N}$ & ND \\
\hline & & $\mathrm{E} 2,3$ & $\mathrm{~N}$ & $\mathrm{~N}$ & $\mathrm{~N}$ & $\mathrm{~N}$ & & & $\mathrm{E} 2,3$ & $\mathrm{~N}$ & $\mathrm{~N}$ & $\mathrm{~N}$ & $\mathrm{~N}$ \\
\hline & \multirow[t]{4}{*}{$0.45-0.5$} & E1 & $\mathrm{S}$ & $S$ & $\mathrm{~S}$ & ND & & $0.45-0.5$ & E1 & S & $S$ & $\mathrm{~S}$ & ND \\
\hline & & E2 & $\mathrm{N}$ & $\mathrm{N}$ & $\mathrm{N}$ & $\mathrm{N}$ & & & E2 & $\mathrm{N}$ & $\mathrm{N}$ & $\mathrm{N}$ & $\mathrm{S}$ \\
\hline & & E3 & $\mathrm{N}$ & $\mathrm{N}$ & $\mathrm{N}$ & S & & & E3 & $\mathrm{N}$ & $\mathrm{N}$ & $\mathrm{N}$ & $\mathrm{S}$ \\
\hline & & $\mathrm{E} 1,2$ & $\mathrm{~N}$ & $\mathrm{~N}$ & $\mathrm{~N}$ & ND & & & $\mathrm{E} 1,2$ & $\mathrm{~N}$ & $\mathrm{~N}$ & $\mathrm{~N}$ & ND \\
\hline
\end{tabular}


Table 3 (continued)

\begin{tabular}{|c|c|c|c|c|c|c|c|c|c|c|c|c|c|}
\hline$C \& D$ waste & $W / C$ & Effects & $R_{1}$ & $R_{2}$ & $R_{3}$ & $R_{4}$ & $C \& D$ waste & $W / C$ & Effects & $R_{1}$ & $R_{2}$ & $R_{3}$ & $R_{4}$ \\
\hline & & $\mathrm{E} 1,3$ & $\mathrm{~N}$ & $\mathrm{~N}$ & $\mathrm{~N}$ & $\mathrm{ND}$ & & & $\mathrm{E} 1,3$ & $\mathrm{~N}$ & $\mathrm{~N}$ & $\mathrm{~N}$ & $\mathrm{ND}$ \\
\hline & & $\mathrm{E} 2,3$ & $\mathrm{~N}$ & $\mathrm{~N}$ & $\mathrm{~N}$ & $\mathrm{~N}$ & & & $\mathrm{E} 2,3$ & $\mathrm{~N}$ & $\mathrm{~N}$ & $\mathrm{~N}$ & $\mathrm{~N}$ \\
\hline & $0.4-0.5$ & E1 & $\mathrm{S}$ & $S$ & $\mathrm{~S}$ & ND & & $0.4-0.5$ & E1 & $S$ & $\mathrm{~S}$ & $\mathrm{~S}$ & ND \\
\hline & & E2 & $\mathrm{N}$ & $\mathrm{N}$ & $\mathrm{N}$ & $\mathrm{N}$ & & & E2 & $\mathrm{N}$ & $\mathrm{N}$ & $\mathrm{N}$ & $\mathrm{N}$ \\
\hline & & E3 & $\mathrm{N}$ & $\mathrm{N}$ & $\mathrm{N}$ & $\mathrm{S}$ & & & E3 & $\mathrm{N}$ & $\mathrm{N}$ & $\mathrm{N}$ & $\mathrm{S}$ \\
\hline & & $\mathrm{E} 1,2$ & $\mathrm{~N}$ & $\mathrm{~N}$ & $\mathrm{~N}$ & $\mathrm{ND}$ & & & $\mathrm{E} 1,2$ & $\mathrm{~N}$ & $\mathrm{~N}$ & $\mathrm{~N}$ & ND \\
\hline & & $\mathrm{E} 1,3$ & $\mathrm{~N}$ & $\mathrm{~N}$ & $\mathrm{~N}$ & $\mathrm{ND}$ & & & $\mathrm{E} 1,3$ & $\mathrm{~N}$ & $\mathrm{~N}$ & $\mathrm{~N}$ & ND \\
\hline & & $\mathrm{E} 2,3$ & $\mathrm{~N}$ & $\mathrm{~N}$ & $\mathrm{~N}$ & $\mathrm{~N}$ & & & $\mathrm{E} 2,3$ & $\mathrm{~N}$ & $\mathrm{~N}$ & $\mathrm{~N}$ & $\mathrm{~N}$ \\
\hline \multirow[t]{18}{*}{$30-50$} & $0.4-0.45$ & E1 & $\mathrm{S}$ & $\mathrm{S}$ & $\mathrm{S}$ & ND & $10-50$ & $0.4-0.45$ & E1 & $\mathrm{S}$ & $\mathrm{S}$ & $\mathrm{S}$ & ND \\
\hline & & E2 & $\mathrm{N}$ & $\mathrm{N}$ & $\mathrm{N}$ & $\mathrm{N}$ & & & E2 & $\mathrm{N}$ & $\mathrm{N}$ & $\mathrm{N}$ & $\mathrm{N}$ \\
\hline & & E3 & $\mathrm{N}$ & $\mathrm{N}$ & $\mathrm{N}$ & $\mathrm{S}$ & & & E3 & $\mathrm{N}$ & $\mathrm{N}$ & $\mathrm{N}$ & $\mathrm{S}$ \\
\hline & & $\mathrm{E} 1,2$ & $\mathrm{~N}$ & $\mathrm{~N}$ & $\mathrm{~N}$ & $\mathrm{~N}$ & & & $\mathrm{E} 1,2$ & $\mathrm{~N}$ & $\mathrm{~N}$ & $\mathrm{~N}$ & ND \\
\hline & & $\mathrm{E} 1,3$ & $\mathrm{~N}$ & $\mathrm{~N}$ & $\mathrm{~N}$ & $\mathrm{~N}$ & & & $\mathrm{E} 1,3$ & $\mathrm{~N}$ & $\mathrm{~N}$ & $\mathrm{~N}$ & ND \\
\hline & & $\mathrm{E} 2,3$ & $\mathrm{~N}$ & $\mathrm{~N}$ & $\mathrm{~N}$ & $\mathrm{~N}$ & & & $\mathrm{E} 2,3$ & $\mathrm{~N}$ & $\mathrm{~N}$ & $\mathrm{~N}$ & $\mathrm{~N}$ \\
\hline & $0.45-0.5$ & E1 & $\mathrm{S}$ & $\mathrm{S}$ & $\mathrm{S}$ & $\mathrm{ND}$ & & $0.45-0.5$ & E1 & $\mathrm{S}$ & $\mathrm{S}$ & $\mathrm{S}$ & ND \\
\hline & & E2 & $\mathrm{N}$ & $\mathrm{N}$ & $\mathrm{N}$ & $\mathrm{N}$ & & & E2 & $\mathrm{N}$ & $\mathrm{N}$ & $\mathrm{N}$ & $\mathrm{N}$ \\
\hline & & E3 & $\mathrm{N}$ & $\mathrm{N}$ & $\mathrm{N}$ & $\mathrm{S}$ & & & E3 & $\mathrm{N}$ & $\mathrm{N}$ & $\mathrm{N}$ & $\mathrm{S}$ \\
\hline & & $\mathrm{E} 1,2$ & $\mathrm{~N}$ & $\mathrm{~N}$ & $\mathrm{~N}$ & ND & & & $\mathrm{E} 1,2$ & $\mathrm{~N}$ & $\mathrm{~N}$ & $\mathrm{~N}$ & ND \\
\hline & & $\mathrm{E} 1,3$ & $\mathrm{~N}$ & $\mathrm{~N}$ & $\mathrm{~N}$ & ND & & & $\mathrm{E} 1,3$ & $\mathrm{~N}$ & $\mathrm{~N}$ & $\mathrm{~N}$ & ND \\
\hline & & $\mathrm{E} 2,3$ & $\mathrm{~N}$ & $\mathrm{~N}$ & $\mathrm{~N}$ & $\mathrm{~N}$ & & & $\mathrm{E} 2,3$ & $\mathrm{~N}$ & $\mathrm{~N}$ & $\mathrm{~N}$ & $\mathrm{~N}$ \\
\hline & $0.4-0.5$ & E1 & $\mathrm{S}$ & $\mathrm{S}$ & $\mathrm{S}$ & ND & & $0.4-0.5$ & E1 & $\mathrm{S}$ & $\mathrm{S}$ & $\mathrm{S}$ & ND \\
\hline & & E2 & $\mathrm{N}$ & $\mathrm{N}$ & $\mathrm{N}$ & $\mathrm{N}$ & & & E2 & $\mathrm{N}$ & $\mathrm{N}$ & $\mathrm{N}$ & $\mathrm{N}$ \\
\hline & & E3 & $\mathrm{N}$ & $\mathrm{N}$ & $\mathrm{N}$ & $\mathrm{S}$ & & & E3 & $\mathrm{N}$ & $\mathrm{N}$ & $\mathrm{N}$ & $\mathrm{S}$ \\
\hline & & $\mathrm{E} 1,2$ & $\mathrm{~N}$ & $\mathrm{~N}$ & $\mathrm{~N}$ & $\mathrm{ND}$ & & & $\mathrm{E} 1,2$ & $\mathrm{~N}$ & $\mathrm{~N}$ & $\mathrm{~N}$ & ND \\
\hline & & $\mathrm{E} 1,3$ & $\mathrm{~N}$ & $\mathrm{~N}$ & $\mathrm{~N}$ & $\mathrm{ND}$ & & & $\mathrm{E} 1,3$ & $\mathrm{~N}$ & $\mathrm{~N}$ & $\mathrm{~N}$ & ND \\
\hline & & $\mathrm{E} 2,3$ & $\mathrm{~N}$ & $\mathrm{~N}$ & $\mathrm{~N}$ & $\mathrm{~N}$ & & & $\mathrm{E} 2,3$ & $\mathrm{~N}$ & $\mathrm{~N}$ & $\mathrm{~N}$ & $\mathrm{~N}$ \\
\hline \multicolumn{7}{|c|}{ Two levels of increment in $C \& D$ waste } & \multicolumn{7}{|c|}{ Four levels of increment in $C \& D$ waste } \\
\hline \multirow[t]{18}{*}{$0-20$} & $0.4-0.45$ & E1 & $\mathrm{S}$ & $\mathrm{S}$ & $\mathrm{S}$ & ND & $0-50$ & $0.4-0.45$ & E1 & $\mathrm{S}$ & $\mathrm{S}$ & $\mathrm{S}$ & ND \\
\hline & & E2 & $\mathrm{N}$ & $\mathrm{N}$ & $\mathrm{N}$ & $\mathrm{S}$ & & & E2 & $\mathrm{N}$ & $\mathrm{S}$ & $\mathrm{S}$ & $\mathrm{S}$ \\
\hline & & E3 & $\mathrm{N}$ & $\mathrm{N}$ & $\mathrm{N}$ & $\mathrm{S}$ & & & E3 & $\mathrm{N}$ & $\mathrm{N}$ & $\mathrm{N}$ & $\mathrm{S}$ \\
\hline & & $\mathrm{E} 1,2$ & $\mathrm{~N}$ & $\mathrm{~N}$ & $\mathrm{~N}$ & $\mathrm{ND}$ & & & $\mathrm{E} 1,2$ & $\mathrm{~N}$ & $\mathrm{~N}$ & $\mathrm{~N}$ & ND \\
\hline & & $\mathrm{E} 1,3$ & $\mathrm{~N}$ & $\mathrm{~N}$ & $\mathrm{~N}$ & ND & & & $\mathrm{E} 1,3$ & $\mathrm{~N}$ & $\mathrm{~N}$ & $\mathrm{~N}$ & ND \\
\hline & & $\mathrm{E} 2,3$ & $\mathrm{~N}$ & $\mathrm{~N}$ & $\mathrm{~N}$ & $\mathrm{~N}$ & & & $\mathrm{E} 2,3$ & $\mathrm{~N}$ & $\mathrm{~N}$ & $\mathrm{~N}$ & $\mathrm{~N}$ \\
\hline & $0.45-0.5$ & E1 & $\mathrm{S}$ & $\mathrm{S}$ & $\mathrm{S}$ & ND & & $0.45-0.5$ & E1 & $\mathrm{S}$ & $\mathrm{S}$ & $\mathrm{S}$ & ND \\
\hline & & E2 & $\mathrm{N}$ & $\mathrm{N}$ & $\mathrm{N}$ & $\mathrm{S}$ & & & E2 & $\mathrm{N}$ & $\mathrm{S}$ & $\mathrm{N}$ & $\mathrm{S}$ \\
\hline & & E3 & $\mathrm{N}$ & $\mathrm{N}$ & $\mathrm{N}$ & $\mathrm{S}$ & & & E3 & $\mathrm{N}$ & $\mathrm{N}$ & $\mathrm{N}$ & $\mathrm{N}$ \\
\hline & & $\mathrm{E} 1,2$ & $\mathrm{~N}$ & $\mathrm{~N}$ & $\mathrm{~N}$ & ND & & & $\mathrm{E} 1,2$ & $\mathrm{~N}$ & $\mathrm{~N}$ & $\mathrm{~N}$ & ND \\
\hline & & $\mathrm{E} 1,3$ & $\mathrm{~N}$ & $\mathrm{~N}$ & $\mathrm{~N}$ & ND & & & E1,3 & $\mathrm{N}$ & $\mathrm{N}$ & $\mathrm{N}$ & ND \\
\hline & & $\mathrm{E} 2,3$ & $\mathrm{~N}$ & $\mathrm{~N}$ & $\mathrm{~N}$ & $\mathrm{~N}$ & & & $\mathrm{E} 2,3$ & $\mathrm{~N}$ & $\mathrm{~N}$ & $\mathrm{~N}$ & $\mathrm{~N}$ \\
\hline & $0.4-0.5$ & E1 & $\mathrm{S}$ & $\mathrm{S}$ & $\mathrm{S}$ & ND & & $0.4-0.5$ & E1 & $\mathrm{S}$ & $\mathrm{S}$ & $\mathrm{S}$ & ND \\
\hline & & E2 & $\mathrm{N}$ & $\mathrm{N}$ & $\mathrm{N}$ & $\mathrm{N}$ & & & E2 & $\mathrm{N}$ & $\mathrm{S}$ & $\mathrm{N}$ & $\mathrm{S}$ \\
\hline & & E3 & $\mathrm{N}$ & $\mathrm{N}$ & $\mathrm{N}$ & $\mathrm{S}$ & & & E3 & $\mathrm{N}$ & $\mathrm{N}$ & $\mathrm{N}$ & $\mathrm{S}$ \\
\hline & & $\mathrm{E} 1,2$ & $\mathrm{~N}$ & $\mathrm{~N}$ & $\mathrm{~N}$ & $\mathrm{ND}$ & & & $\mathrm{E} 1,2$ & $\mathrm{~N}$ & $\mathrm{~N}$ & $\mathrm{~N}$ & ND \\
\hline & & $\mathrm{E} 1,3$ & $\mathrm{~N}$ & $\mathrm{~N}$ & $\mathrm{~N}$ & ND & & & $\mathrm{E} 1,3$ & $\mathrm{~N}$ & $\mathrm{~N}$ & $\mathrm{~N}$ & ND \\
\hline & & $\mathrm{E} 2,3$ & $\mathrm{~N}$ & $\mathrm{~N}$ & $\mathrm{~N}$ & $\mathrm{~N}$ & & & $\mathrm{E} 2,3$ & $\mathrm{~N}$ & $\mathrm{~N}$ & $\mathrm{~N}$ & $\mathrm{~N}$ \\
\hline
\end{tabular}

$N$ nonsignificant, $S$ significant, $N D$ not defined 
The results of statistical analysis are given in Table 3 addressing one, two, three, and four levels of increment in C\&D waste content, respectively. The results show that the effect of curing time $\left(E_{1}\right)$ on compressive strength, tensile strength, and flexural strength is significant regardless of $W / C$ ratio and C\&D waste content. Moreover, the $W / C$ ratio $\left(E_{3}\right)$ has a significant effect on slump except for $C \& D$ waste: $0-50 \%, W / C: 0.45-0.5$. It is well established that the curing time has a substantial effect on the strengths, and with an increase in curing time, strength increases considerably. It is also true for concrete mixtures containing RA. Also, changes in $W / C$ ratio have a significant effect on slump within 0.4-0.5, and with an increase in water-to-cement ratio slump increases remarkably.

The sensitivity analysis indicates that, for $0-10 \%$, $0-20 \%$, and $0-30 \%$ replacement, both $0.4-0.45$ and $0.45-0.5 \mathrm{~W} / \mathrm{C}$ ratios result in a significant effect on slump. $\mathrm{C} \& \mathrm{D}$ waste materials have no significant influence on compressive, tensile, and flexural strengths until four levels of increment in their content. For $0-50 \%$ replacement, $W / C$ ratio increases of $0.4-0.45,0.45-0.5$, and $0.4-0.5$ lead to a significant effect on tensile and flexural strength. In contrast, $C \& D$ waste materials even in their most intense variation in level, i.e., from 0 to $50 \%$, have no significant influence in compressive strength.

It can be concluded from statistical analysis that RA has a great impact on workability. This is due to the rough surface texture of RA with more pores and cavities compared to VA. Not only does the rough texture of RA absorb more water than VA, it also increases the friction between particles. Therefore, less effective water for lubrication and greater friction as a result of RA addition result in significant slump reduction.

\section{Conclusion}

In this study, the use of construction and demolition debris as a replacement for coarse aggregates in concrete was evaluated with regard to workability, compressive, tensile, and flexural strengths. The results indicated that the use of recycled aggregate (RA) has a significant negative effect on workability. Although the addition of RA decreases compressive strength, the strength reduction is not significant even by comparing the highest RA replacement with the lowest one. Since the effect of $W / C$ ratio from 0.4 to 0.5 is not significant on compressive strength, higher $W / C$ ratio can be used in order to compensate the slump decrease due to RA application.

With respect to tensile and flexural strengths, just the highest RA content change from 0 to $50 \%$ can make an influential decline in them. All in all, it can be concluded that construction and demolition (C\&D) waste materials are a suitable surrogate for natural virgin aggregates up to $50 \%$ and up to 0.5 of $W / C$ ratio can be applied to mitigate the negative impact of them on workability.

Open Access This article is distributed under the terms of the Creative Commons Attribution 4.0 International License (http://creativecommons.org/licenses/by/4.0/), which permits unrestricted use, distribution, and reproduction in any medium, provided you give appropriate credit to the original author(s) and the source, provide a link to the Creative Commons license, and indicate if changes were made.

\section{References}

1. Eckert M, Oliveira M (2017) Mitigation of the negative effects of recycled aggregate water absorption in concrete technology. Constr Build Mater 133:416-424

2. Kartam N, Al-Mutairi N, Al-Ghusain I, Al-Humoud J (2004) Environmental management of construction and demolition waste in Kuwait. Waste Manag 24:1049-1059

3. Marzouk M, Azab S (2014) Environmental and economic impact assessment of construction and demolition waste disposal using system dynamics. Resour Conserv Recycl 82:41-49

4. Bravo M, De Brito J, Pontes J, Evangelista L (2015) Mechanical performance of concrete made with aggregates from construction and demolition waste recycling plants. J Clean Prod 99:59-74

5. Fatemi S, Imaninasab R (2016) Performance evaluation of recycled asphalt mixtures by construction and demolition waste materials. Constr Build Mater 120:450-456

6. Ahmadi M, Farzin S, Hassani A, Motamedi M (2017) Mechanical properties of the concrete containing recycled fibers and aggregates. Constr Build Mater 144:392-398

7. Evangelista L, de Brito J (2007) Mechanical behaviour of concrete made with fine recycled concrete aggregates. Cem Concr Compos 29:397-401

8. Khatib JM (2005) Properties of concrete incorporating fine recycled aggregate. Cem Concr Res 35:763-769

9. Awall R, Rahaman O, Azad S, Rabbi Sh (2017) Compressive strength behavior of concrete by partial replacement of regular brick with over-burnt brick aggregate. Innov Infrastruct Solut 2:11

10. Gandi A, Carter A, Singh D (2017) Rheological behavior of cold recycled asphalt materials with different contents of recycled asphalt pavements. Innov Infrastruct Solut 2:45

11. Awoyera P, Akinmusuru J, Moncea A (2017) Hydration mechanism and strength properties of recycled aggregate concrete made using ceramic blended cement. Civ Environ Eng 4-1282667

12. Marinković S, Radonjanin V, Malešev M, Ignjatović I (2010) Comparative environmental assessment of natural and recycled aggregate concrete. Waste Manag 30:2255-2264

13. Mas B, Cladera A, del Olmo T, Pitarch F (2012) Influence of the amount of mixed recycle aggregates on the properties of concrete for non-structural use. Constr Build Mater 27:612-622

14. Etxeberria M, Vázquez E, Marí A, Barra M (2007) Influence of amount of recycled coarse aggregates and production process on properties of recycled aggregate concrete. Cem Concr Res 37:735-742

15. Crentsil Sagoe K, Brown T, Taylor A (2001) Performance of concrete made with commercially produced coarse recycled concrete aggregate. Cem Concr Res 31:707-712

16. Ajdukiewicz A, Kliszczewicz A (2002) Influence of recycled aggregates on mechanical properties of HS/HPC. Cem Concr Compos 24:269-279

17. McNeil K, Kang TH-K (2013) Recycled concrete aggregates: a review. Int J Concr Struct Mater 7:61-69 
18. Carneiro CA, Lima MB, Leite RDT (2014) Compressive stressstrain behavior of steel fiber reinforced-recycled aggregate concrete. Cement Concr Compos 46:886-893

19. Castro S, De Brito J (2013) Evaluation of the durability of concrete made with crushed glass aggregates. J Clean Prod 41:7-14

20. Anderson D, Smith S, Francis TK (2016) Mechanical properties of concrete utilising waste ceramic as coarse aggregate. Constr Build Mater 117:20-28

21. Rao A, Kumar N, Sudhir M (2007) Use of aggregates from recycled construction and demolition waste in concrete. Resour Conserv Recycl 50:71-81

22. National Building Regulations Office (2014) Topic ninth. Design and implementation of reinforced concrete building, pp 116-117
23. Safiuddin M, Salam M, Jumaat M (2011) Effects of recycled concrete aggregate on the fresh properties of self-consolidating concrete. Arch Civ Mech Eng 11:1023-1041

24. Leite A, Gualberto J, Filho F, Lima P (2012) Workability study of concretes made with recycled mortar aggregate. Mater Struct 46:1765-1778

25. López-Gayarre F, López-Colina C, Serrano-López MA, García Taengua E, Lópe Martínez A (2011) Assessment of properties of recycled concrete by means of a highly fractioned factorial design of experiment. Constr Build Mater 25:3802-3809 